\title{
Comparative Evaluation of the Antioxidant Capacities, Organic Acids, and Volatiles of Papaya Juices Fermented by Lactobacillus acidophilus and Lactobacillus plantarum
}

\author{
Ronghao Chen, Wenxue Chen $\mathbb{D}$, Haiming Chen $\mathbb{D}$, Guanfei Zhang, and Weijun Chen \\ College of Food Science and Technology, Hainan University, Haikou, Hainan 570228, China \\ Correspondence should be addressed to Weijun Chen; chenwj@hainu.edu.cn
}

Received 30 July 2017; Revised 7 November 2017; Accepted 13 December 2017; Published 3 January 2018

Academic Editor: Jorge Barros-Velázquez

Copyright (c) 2018 Ronghao Chen et al. This is an open access article distributed under the Creative Commons Attribution License, which permits unrestricted use, distribution, and reproduction in any medium, provided the original work is properly cited.

Fermentation of foods by lactic acid bacteria is a useful way to improve the nutritional value of foods. In this study, the health-promoting effects of fermented papaya juices by two species, Lactobacillus acidophilus and Lactobacillus plantarum, were determined. Changes in $\mathrm{pH}$, reducing sugar, organic acids, and volatile compounds were determined, and the vitamin $\mathrm{C}$, total phenolic content, and flavonoid and antioxidant capacities during the fermentation process were investigated. Juices fermented by Lactobacillus acidophilus and Lactobacillus plantarum had similar changes in $\mathrm{pH}$ and reducing sugar content during the $48 \mathrm{~h}$ fermentation period. Large amounts of aroma-associated compounds and organic acids were produced, especially lactic acid, which increased significantly $(p<0.05)(543.18 \mathrm{mg} / 100 \mathrm{~mL}$ and $571.29 \mathrm{mg} / 100 \mathrm{~mL}$, resp.), improving the quality of the beverage. In contrast, the production of four antioxidant capacities in the fermented papaya juices showed different trends after 48 hours' fermentation by two bacteria. Lactobacillus plantarum generated better antioxidant activities compared to Lactobacillus acidophilus after $48 \mathrm{~h}$ of fermentation. These results indicate that fermentation of papaya juice can improve its utilization and nutritional effect.

\section{Introduction}

Lactic acid fermentation is one of the oldest and most economical methods used in food preservation, especially as a "natural" process that enhances the efficacy and quality of foods while improving the organoleptic qualities of the product $[1-3]$. In fact, at the end of the twentieth century, the Food and Agriculture Organization (FAO) of the United Nations recognized the importance of fermented products, highlighting their economic importance for local communities in developing countries [4]. Probiotic foods are an important and dominating part of the functional food market, accounting for $60 \%$ to $70 \%$ of the total functional food market [5], with more than 370 products launched worldwide in Japan and Europe in 2005 [6]. A number of studies have reported that the development of fruit juice-based fermented beverages would be the next food category in which healthpromoting probiotic bacteria will make their mark $[7,8]$. Many countries have conducted extensive research and development on probiotic-fermented fruit and vegetable beverages in recent years, especially in Korea, India, and Brazil. These studies have used watermelons, tomatoes, apples, and so on as raw materials for fermentation by lactic acid bacteria [911]. An important aspect of lactic acid bacteria (LAB) fermentation is the production of organic acids, sugar polymers, aromatic compounds, vitamins, polyphenolic compounds, and some useful enzymes, which enrich the human diet $[12,13]$. The fermentation products generated by different lactic acid bacteria are not the same. Lee et al. [14] showed variations among the respective $\mathrm{LAB}$ strains from kimchi, and Kumar et al. [15] showed that L. plantarum Lp91 has a better effect than Lp21 in the management of hypercholesterolaemia. Thus, significant differences in the antioxidant activity and composition of fermented products can be generated by specific probiotic strains [16].

Papaya (Carica papaya L.), a member of the Caricaceae family, is widely cultivated in tropical and subtropical regions and is marketed around the world for its great taste and nutrients $[17,18]$. Papaya has been identified as a valuable source of nutrients and antioxidants and is also used for traditional 
medicine. Its fruits, stems, leaves, and roots are used in a wide range of medical applications, including the production of two important bioactive compounds (chymopapain and papain), which are widely used for digestive diseases [1921]. However, postharvest losses of papaya occur throughout the value chain due to rapid deterioration of its chemical components and pulp softening, which results in a short shelf life of the fresh fruit [22, 23]. Many studies have demonstrated the feasibility of using fruits, such as oranges, pineapples, bananas, and cranberries, to produce probiotic beverages [24]. However, other fruits, such as papaya, have not been adequately studied. Thus far, only a small amount of research has been conducted on fermented papaya beverages. Among these, most have studied the use of papaya for wine-making [25, 26]. Di Cagno et al. [27] demonstrated the growth and survival of L. plantarum and L. pentosus in a papaya juice-based medium. All of these studies have demonstrated that papaya beverages are suitable for microbial growth. To explore the feasibility of LAB fermentation of papaya beverages to improve the utilization value of papaya, this study assessed two lactic acid bacteria for fermentation.

\section{Materials and Methods}

\subsection{Materials}

Samples and Bacteria. Papaya puree, skim milk powder, and edible glucose were purchased from the Nanguo Supermarket and Hainan Dachuan Food Co., Ltd. (Haikou, China). Lactobacillus acidophilus GIM1.731 (L. acidophilus) and Lactobacillus plantarum GIM1.140 (L. plantarum) were purchased from Guangdong Microbiology Culture Center (Guangzhou, China).

Preparation of Papaya Juices and Fermentation. Each sample was formulated to $200 \mathrm{~g}$ for fermentation. According to mass, $45 \%$ papaya puree, $45 \%$ distilled water, $5 \%$ edible glucose, and $5 \%$ skim milk powder (10-fold diluted skim milk powder) were added to a conical flask, heat sterilized at $90^{\circ} \mathrm{C}$ for $10 \mathrm{~min}$, and then cooled in a water bath. Each LAB strain was inoculated at $5 \%$ of the mass ratio of the fermentation broth, and the mixture was incubated at $37^{\circ} \mathrm{C}$ for $48 \mathrm{~h}$ under static conditions. Samples were stored at $-80^{\circ} \mathrm{C}$. Fermentation processes were repeated three times.

\subsection{Methods}

2.2.1. Determination of $p H$. The $\mathrm{pH}$ of the samples was measured by a digital $\mathrm{pH}$ meter (FE20 laboratory $\mathrm{pH}$ meter).

2.2.2. Determination of Reducing Sugars. The reducing sugars content of fermented juice was analyzed as glucose equivalents by the 3,5-dinitrosalicylic acid (DNS) method of Saqib [28] with some modification. In this application, $2 \mathrm{~mL}$ of 250 fold diluted sample and $4 \mathrm{~mL}$ DNS reagent were added to the 10 -mL graduated tube and heated in a boiling water bath for 5 minutes. When removed, the tube was immediately placed in cold water, cooled to room temperature, supplemented with water to $10 \mathrm{~mL}$, and shaken well. The absorbance was measured at $540 \mathrm{~nm}$. The results were expressed as milligrams of glucose equivalents.

2.2.3. Determination of Vitamin C. The 2,6-dichlorophenolindophenol titrimetric method was used to measure the levels of reduced ascorbic acid [29].

2.2.4. Determination of Total Phenolic Content. Extracts were prepared by mixing $5 \mathrm{~g}$ of sample with $25 \mathrm{~mL}$ of $50 \%$ ethanol. The mixture was placed in a thermostat oscillator set at $100 \mathrm{r} / \mathrm{min}$ for $1 \mathrm{~h}$ and was then centrifuged at $4000 \mathrm{r} / \mathrm{min}$ for $10 \mathrm{~min}$. Extracts were transferred into test conical flasks and stored at $4^{\circ} \mathrm{C}$ before analysis. Total phenolic content was determined using the Folin-Ciocalteu method described by de Sà et al. [30] with some modifications. A $1 \mathrm{~mL}$ aliquot of each fermented papaya beverage extract was mixed with $0.2 \mathrm{~mL}$ of Folin-Ciocalteu's reagent and was incubated at room temperature for $3 \mathrm{~min}$. Then, the mixture was dissolved in $7.5 \% \mathrm{Na}_{2} \mathrm{CO}_{3}$ and adjusted to a volume of $10 \mathrm{~mL}$. After $30 \mathrm{~min}$, the absorbance was measured at $765 \mathrm{~nm}$. The results were expressed as milligrams of gallic acid equivalents (GAE).

2.2.5. Determination of Total Flavonoids Content. The total flavonoids content of samples was measured according to the method of $\mathrm{Wu}$ et al. [31] with some modifications. A $0.6 \mathrm{~mL}$ aliquot of each sample was mixed with $1.2 \mathrm{~mL}$ of $80 \%$ methanol; then $0.18 \mathrm{~mL}$ of $20 \% \mathrm{NaNO}_{2}$ was added. After $6 \mathrm{~min}, 0.36 \mathrm{~mL}$ of $8 \% \mathrm{Al}\left(\mathrm{NO}_{3}\right)_{3}$ was added, followed by the addition of $1.2 \mathrm{~mL}$ of $1 \mathrm{~mol} / \mathrm{L} \mathrm{NaOH}$ after $5 \mathrm{~min}$. After $15 \mathrm{~min}$, the absorbance was measured at $510 \mathrm{~nm}$. The results were expressed as milligrams of rutin equivalents (RE).

2.2.6. Determination of Total Carotenoid Content. The total carotenoid content was measured according to the method of Carbonell-Capella et al. [32] with some modification. A $1 \mathrm{~mL}$ aliquot of each sample was homogenized with $5 \mathrm{~mL}$ of extraction solvent (hexane/acetone/methanol, $50: 25: 25$, $v / v)$. The mixture was placed in a thermostat oscillator set at $100 \mathrm{r} / \mathrm{min}$ for $30 \mathrm{~min}$ and then was centrifuged at $6000 \mathrm{r} / \mathrm{min}$ at $4^{\circ} \mathrm{C}$ for $10 \mathrm{~min}$. The top, colored hexane layer was recovered and transferred to a $25 \mathrm{~mL}$ volumetric flask, and the volume was then adjusted to $25 \mathrm{~mL}$ with hexane. The absorbance of the samples was measured at $450 \mathrm{~nm}$. The results were calculated as described by Ritter and Purcell (1981) using the extinction coefficient of $\beta$-carotene, $E^{1 \%}=2505$.

\subsubsection{Determination of the Total Antioxidant Capacity In Vitro}

(1) 2,2-Diphenyl-1-Picrylhydrazyl (DPPH) Radical Scavenging Assay. The $\mathrm{DPPH}^{\bullet+}$ assay was performed according to $\mathrm{Li}$ et al. [33] with some modifications. Briefly, $0.02 \mathrm{~g}$ of DPPH was transferred to a $25 \mathrm{~mL}$ volumetric flask, the volume was adjusted to $25 \mathrm{~mL}$ with methanol, and, after the flask was fully oscillated, the solution was subjected to ultrasound for $5 \mathrm{~min}$. The $0.8 \mathrm{mg} / \mathrm{mL}$ solution of DPPH in methanol was diluted with methanol until the solution had an absorbance of 1.2-1.3 at $517 \mathrm{~nm}$. A $0.12 \mathrm{~mL}$ aliquot of sample was added to $4 \mathrm{~mL}$ of the DPPH radical solution. The mixture was incubated in the 
dark for $45 \mathrm{~min}$, after which the absorbance was measured at $517 \mathrm{~nm}$. The DPPH radical scavenging activity (\% inhibition) was calculated using the formula $\left(1-A_{1} / A_{0}\right) \times 100$, where $A_{0}$ is the absorbance of the reagent blank and $A_{1}$ is the absorbance of the sample.

(2) 2,2'-Azinobis-(3-Ethylbenzothiazoline-6-Sulfonate) (ABTS) Radical Scavenging Assay. The ABTS ${ }^{++}$assay was performed according to Um et al. [34] with some modification. First, $0.192 \mathrm{~g}$ of ABTS and $0.067 \mathrm{~g}$ of $\mathrm{K}_{2} \mathrm{~S}_{2} \mathrm{O}_{8}$ were dissolved in phosphate buffered saline (PBS, $\mathrm{pH}=7$ ), transferred to a 50 $\mathrm{mL}$ volumetric flask and the volume was adjusted to $50 \mathrm{~mL}$. The working solution of $\mathrm{ABTS}^{+\bullet}$ was obtained by diluting the stock solution in PBS to give an absorption of $0.70 \pm 0.02$ at $734 \mathrm{~nm}$. A $50 \mu \mathrm{L}$ aliquot of each sample was added to $4 \mathrm{~mL}$ of the $\mathrm{ABTS}^{+\bullet}$ solution and absorbance readings at $734 \mathrm{~nm}$ were taken at every $10 \mathrm{~min}$.

The ABTS radical scavenging activity (\% inhibition) was calculated using the formula $\left(1-A_{1} / A_{0}\right) \times 100$, where $A_{0}$ is the absorbance of the reagent blank and $A_{1}$ is the absorbance of the sample.

(3) Ferric Reducing Antioxidant Power (FRAP) Assay. The antioxidant capacity was determined using the FRAP assay, which was performed according to Morales-Soto et al. [35] with some modification. The freshly prepared FRAP solution contained $25 \mathrm{~mL}$ of $0.3 \mathrm{~mol} / \mathrm{L}$ acetate buffer $(\mathrm{pH} \mathrm{3.6)}$ ), $2.5 \mathrm{~mL}$ of $10 \mathrm{mmol} / \mathrm{L}$ 2,4,6-tripyridyl-1,3,5-triazine (TPTZ) (dissolved in $40 \mathrm{mmol} / \mathrm{L} \mathrm{HCl}$ ), and $2.5 \mathrm{~mL}$ of $20 \mathrm{mmol} / \mathrm{L} \mathrm{fer-}$ ric chloride. A $0.2 \mathrm{~mL}$ aliquot of each 10 -fold diluted sample was mixed with $4 \mathrm{~mL}$ of FRAP solution and was incubated for $50 \mathrm{~min}$ at room temperature. The ferric reducing ability was measured by monitoring the absorbance at $593 \mathrm{~nm}$ using a spectrophotometer (TU-1810, Puxi, Beijing, China) and the FRAP solution was used as a blank. $\mathrm{FeSO}_{4}$ was used as a control to obtain the standard curve. The FRAP values were calculated relative to the activity of $\mathrm{FeSO}_{4}$ and expressed as $\mathrm{FeSO}_{4}$ equivalents.

(4) Cupric Ion Reducing Antioxidant Capacity (CUPRAC) Assay. The typical CUPRAC method, as described by Kondakçi et al. [36], was performed as follows. A solution comprised of $1 \mathrm{~mL}$ of $5 \mathrm{mmol} / \mathrm{L}$ copper sulfate, $1 \mathrm{~mL}$ of $3.75 \mathrm{mmol} / \mathrm{L}$ neocuproine (dissolved in methanol), and $1 \mathrm{~mL}$ of ammonium acetate buffer at $\mathrm{pH} 7.0$ was prepared. Then, $0.1 \mathrm{~mL}$ of sample solution and $0.9 \mathrm{~mL}$ of distilled water were added and well mixed. This final mixture was incubated at room temperature for $30 \mathrm{~min}$ in a stoppered test tube, after which the absorbance at $450 \mathrm{~nm}$ was measured against a reagent blank. Trolox solution was used as a control to obtain the standard curve. The CUPRAC value was calculated relative to the activity of trolox and was expressed as trolox equivalents.

2.2.8. Liquid Chromatography Analysis of Organic Acids. To avoid affecting the determination of the organic acid content, the supernatant was obtained by centrifugation before the measurement to remove the protein [37]. In brief, $2 \mathrm{~mL}$ of sample was added to $2 \mathrm{~mL}$ of a solution in $1.8 \% \mathrm{Ba}(\mathrm{OH})_{2}$, adding $2 \mathrm{~mL}$ of a solution of $2 \% \mathrm{ZnSO}_{4}$. The mixture was vortex shaken, allowed to settle for $15 \mathrm{~min}$, and centrifuged at $8000 \mathrm{r} / \mathrm{min}$ for $10 \mathrm{~min}$. Measurements of organic acid contents were performed according to the method described by Zhao et al. [38]. The sample was filtered through a $0.22 \mu \mathrm{m}$ pore size membrane filter before injection. An HPLC system (Agilent 1260, Agilent Technologies Inc., USA) equipped with a pump system and a UV-visible detector was used to monitor the absorbance at $210 \mathrm{~nm}$ for the analysis of organic acids. Organic acids were simultaneously analyzed on a ZORBAX SB-Aq column $(250 \mathrm{~mm} \times$ $4.6 \mathrm{~mm}, 5 \mu \mathrm{m}$ ) (Agilent, Agilent Technologies Inc., USA), which was kept at $30^{\circ} \mathrm{C}$. The assay conditions used were as follows: the flow was set at $0.8 \mathrm{~mL} / \mathrm{min}$ and the eluent consisted of $0.02 \mathrm{~mol} / \mathrm{L}$ ammonium dihydrogen phosphate ( $\mathrm{pH} 2.66$, adjust $\mathrm{pH}$ by phosphate) with $3 \%$ methanol. The flow ratio was isocratic elution of Solvent A (ammonium dihydrogen phosphate): Solvent B (methanol) $(97: 3)$. The chromatographic peaks corresponding to each organic acid were identified by comparing the retention times with those of standards. For each compound, a calibration curve was prepared using standards to determine the relationship between the peak area and organic acid concentration.

2.2.9. Analysis of Volatile Compounds. The volatile compound analysis was performed according to the method described by Fuggate et al. [39] with some modification. Volatile components in the headspace were trapped by solid phase microextraction (SPME). The dioctanol was used as an internal standard. For each sample, a $1 \mathrm{~mL}$ aliquot was taken from a $20 \mathrm{~mL}$ sealed headspace bottle. A CTC Trinity Autosampler was used for all assays, with a SPME fibre of 50/30 $\mu \mathrm{m}$ DVB/CAR/PDMS. The following extraction conditions were used: temperature, $50^{\circ} \mathrm{C}$; equilibration of the fibre, $15 \mathrm{~min}$; extraction time, $30 \mathrm{~min}$; agitation speed, $250 \mathrm{r} / \mathrm{min}$; injection time, $4 \mathrm{~min}$.

A USA Agilent 7890A-5975C Gas Chromatography-Mass Spectrometer (GC-MS) equipped with a DB-wax (30 m long $\times 0.25 \mathrm{mmID} \times 0.25 \mu \mathrm{m} \mathrm{df}$ ) column was used for all analyses. The chromatographic conditions included a flow rate of $1 \mathrm{~mL} / \mathrm{min}$ using helium $(99.999 \%)$ as a carrier gas and an injection temperature of $260^{\circ} \mathrm{C}$. The column temperature was maintained at $40^{\circ} \mathrm{C}$ for $5 \mathrm{~min}$, was ramped at $5^{\circ} \mathrm{C} / \mathrm{min}$ to $250^{\circ} \mathrm{C}$, and then was held for $5 \mathrm{~min}$. The power supply mode was set to electronic ionization (EI). The interface, ion source, and quadrupole temperatures were 260,230 , and $150^{\circ} \mathrm{C}$, respectively; the electron energy used was $70 \mathrm{eV}$, and the detector voltage was $2235 \mathrm{~V}$; the scan mode was set at full scan with a mass range of 20-400 amu, using the NIST 2011 library.

2.2.10. Statistical Analysis. The statistical analysis was conducted with DPS ver. 15.10 software and SPSS ver. 17.0 software (Chicago, IL, USA). Results were recorded as the means \pm standard deviation (SD) of triplicate experiments. Analysis of variance (ANOVA) was performed on data sets, and significant differences $(p<0.01$ and $p<0.05)$ between the means were determined by Duncan's multiple range test. 

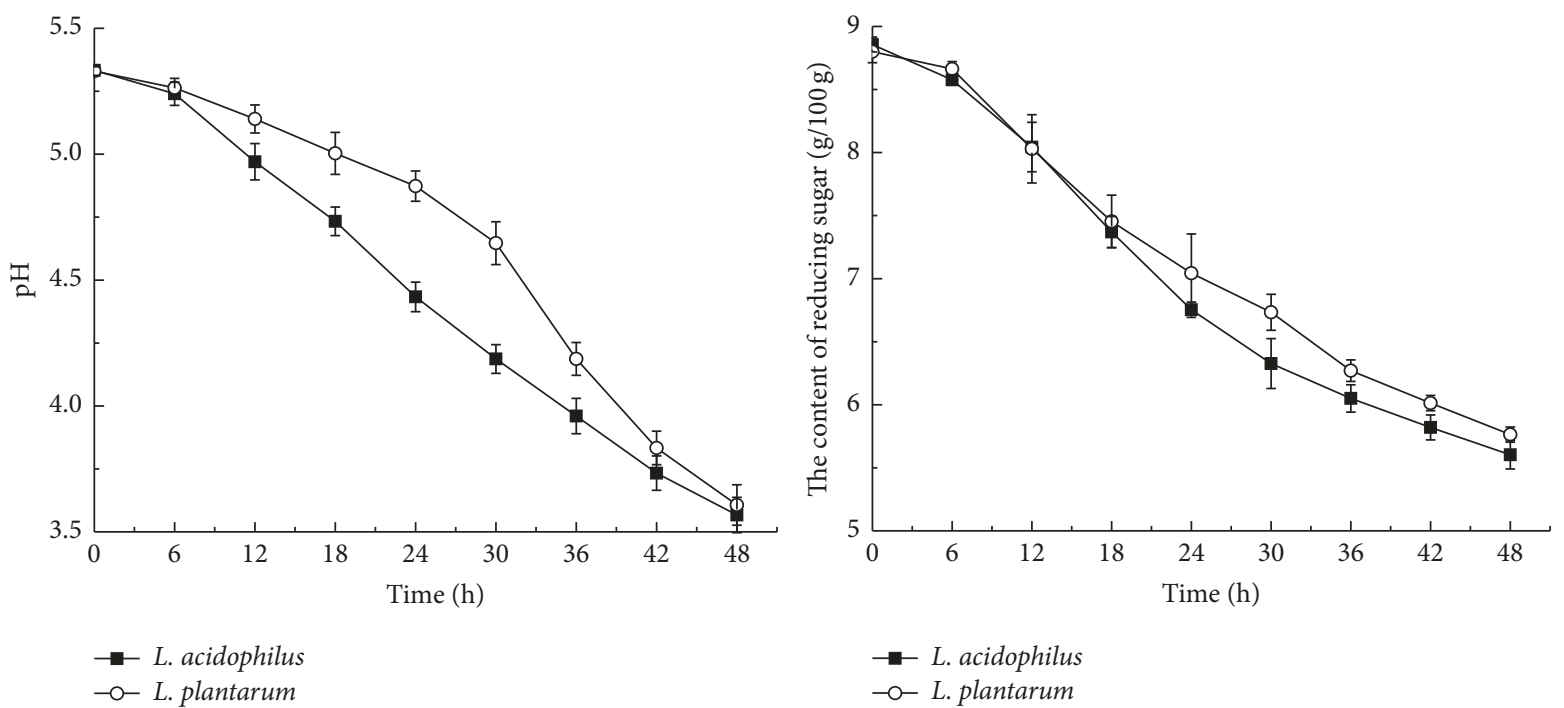

FIgURE 1: Changes in $\mathrm{pH}$ and reducing sugar content of the fermented papaya juices.

\section{Results and Discussion}

3.1. Fermentation Characteristics of the Papaya Juice during the $48 \mathrm{~h}$ Fermentation. The $\mathrm{pH}$ value is an important parameter to gauge the progress and end point of lactic acid fermentation, influencing the flavor of the fermented product [40]. The two cultures showed similar characteristics with respect to changes in $\mathrm{pH}$ values and in the content of reducing sugars. The changes in $\mathrm{pH}$ values of the two probiotic cultures are shown in Figure 1, with the $\mathrm{pH}$ of both cultures decreasing significantly during the fermentation process $(p<0.05)$. For example, after $48 \mathrm{~h}$ fermentation the $\mathrm{pH}$ of fermented papaya juice with L. acidophilus (FPJA) decreased from 5.36 to 3.60 , and the $\mathrm{pH}$ of fermented papaya juice with $L$. plantarum (FPJP) decreased from 5.34 to 3.55 . Klupsaite et al. [41] reported that the fermentation of narrow-leaved lupine resulted in similar changes in $\mathrm{pH}$ values. Changes in reducing sugar content of the fermented papaya juices are shown in Figure 1, and the content of reducing sugar of both FPJA and FPJP decreased significantly during fermentation $(p<0.05)$. The reducing sugar content of FPJA decreased from $8.86 \mathrm{~g} / 100 \mathrm{~g}$ to $5.60 \mathrm{~g} / 100 \mathrm{~g}$, and the reducing sugar content of FPJP decreased from $8.80 \mathrm{~g} / 100 \mathrm{~g}$ to $5.76 \mathrm{~g} / 100 \mathrm{~g}$. However, the fermented papaya juices still had a high content of reducing sugar, retaining enough sweetness.

\subsection{The Relationship between Antioxidative Components and Antioxidant Capacities}

3.2.1. Antioxidative Components of the Fermented Papaya Juices after the $48 \mathrm{~h}$ Fermentation Period. A large number of studies analyzing the bioactive composition of papaya have been reported. Papaya is rich in total phenols, carotenoids, flavonoids, vitamin C, and other bioactive substances [42]. The total phenolic content of FPJA decreased more significantly than that of FPJP, as shown in Table $1(p<0.05)$. The
TABLE 1: Changes in total phenolic content of the fermented papaya juices.

\begin{tabular}{lcc}
\hline Fermentation time $(\mathrm{h})$ & $\begin{array}{c}\text { Total phenolic content of the fermented } \\
\text { papaya juices }(\mathrm{mg} / 100 \mathrm{~g})\end{array}$ \\
& $\begin{array}{c}\text { L. acidophilus } \\
\text { L. plantarum }\end{array}$ \\
\hline 0 & $31.9 \pm 0.6^{\mathrm{a}}$ & $32.1 \pm 0.8^{\mathrm{ab}}$ \\
6 & $28.8 \pm 0.5^{\mathrm{cd}}$ & $31.9 \pm 0.4^{\mathrm{ab}}$ \\
12 & $30.2 \pm 0.3^{\mathrm{bc}}$ & $29.8 \pm 0.4^{\mathrm{c}}$ \\
18 & $30.7 \pm 0.7^{\mathrm{ab}}$ & $32.5 \pm 1.8^{\mathrm{a}}$ \\
24 & $31.1 \pm 0.8^{\mathrm{ab}}$ & $30.7 \pm 0.8^{\mathrm{bc}}$ \\
30 & $32.1 \pm 0.8^{\mathrm{a}}$ & $33.0 \pm 1.5^{\mathrm{a}}$ \\
36 & $29.1 \pm 1.97^{\mathrm{c}}$ & $31.7 \pm 1.6^{\mathrm{ab}}$ \\
42 & $27.4 \pm 0.4^{\mathrm{de}}$ & $30.5 \pm 0.5^{\mathrm{bc}}$ \\
48 & $27.2 \pm 0.9^{\mathrm{e}}$ & $29.5 \pm 0.6^{\mathrm{c}}$
\end{tabular}

Values are expressed as the mean \pm SD. Values with different letters $(\mathrm{a} \sim \mathrm{e})$ in the same column are significantly different at $p<0.05$.

total phenolic content of FPJA decreased from $31.89 \mathrm{mg} / 100 \mathrm{~g}$ to $27.16 \mathrm{mg} / 100 \mathrm{~g}$, a decrease of $14.83 \%$, while the total phenolic content of FPJP decreased from $32.09 \mathrm{mg} / 100 \mathrm{~g}$ to $29.53 \mathrm{mg} / 100 \mathrm{~g}$, representing a decrease of $7.98 \%$. The total flavonoids content of both FPJA and FPJP increased significantly after fermentation as shown in Table $2(p<$ 0.05). The total flavonoids content of FPJA increased from $0.50 \mathrm{mg} / 100 \mathrm{~g}$ to $1.11 \mathrm{mg} / 100 \mathrm{~g}$, and the total flavonoids content of FPJP increased to $1.45 \mathrm{mg} / 100 \mathrm{~g}$. The total carotenoid content of FPJA decreased from $15.47 \mathrm{mg} / 100 \mathrm{~g}$ to $11.48 \mathrm{mg} / 100 \mathrm{~g}$, and vitamin $\mathrm{C}$ content decreased from $21.11 \mathrm{mg} / 100 \mathrm{~g}$ to $17.56 \mathrm{mg} / 100 \mathrm{~g}$. The total carotenoid content of FPJP decreased from $15.47 \mathrm{mg} / 100 \mathrm{~g}$ to $11.15 \mathrm{mg} / 100 \mathrm{~g}$, and the vitamin $\mathrm{C}$ content decreased from $21.11 \mathrm{mg} / 100 \mathrm{~g}$ to $18.22 \mathrm{mg} / 100 \mathrm{~g}$. 
TABLE 2: Changes in others antioxidative components of the fermented papaya juices.

\begin{tabular}{lccc}
\hline $\begin{array}{l}\text { Antioxidative } \\
\text { components }\end{array}$ & $\begin{array}{c}\text { Papaya juice } \\
(\mathrm{mg} / 100 \mathrm{~mL})\end{array}$ & $\begin{array}{c}\text { L. acidophilus } \\
48 \mathrm{~h} \\
(\mathrm{mg} / 100 \mathrm{~mL})\end{array}$ & $\begin{array}{c}\text { L. plantarum } \\
(\mathrm{mg} / 100 \mathrm{~mL})\end{array}$ \\
\hline $\begin{array}{l}\text { Total flavonoids } \\
\text { content }\end{array}$ & $0.50 \pm 0.06^{\mathrm{c}}$ & $1.11 \pm 0.17^{\mathrm{b}}$ & $1.45 \pm 0.13^{\mathrm{a}}$ \\
$\begin{array}{l}\text { Total carotenoid } \\
\text { content }\end{array}$ & $15.5 \pm 1.3^{\mathrm{a}}$ & $11.5 \pm 1.3^{\mathrm{b}}$ & $11.1 \pm 1.0^{\mathrm{b}}$ \\
$\begin{array}{l}\text { Vitamin C } \\
\text { content }\end{array}$ & $21.1 \pm 1.0^{\mathrm{a}}$ & $17.6 \pm 1.0^{\mathrm{b}}$ & $18.22 \pm 1.0^{\mathrm{b}}$ \\
\hline
\end{tabular}

Values are expressed as the mean $\pm \mathrm{SD}$. Values with different letters $(\mathrm{a} \sim \mathrm{c})$ in the same column are significantly different at $p<0.05$.

\subsubsection{Antioxidative Activity of the Fermented Papaya Juices} after the $48 \mathrm{~h}$ Fermentation Period. Different antioxidant compounds may act against oxidizing agents through distinct mechanisms so that a single isolation method cannot completely evaluate the antioxidant capacity of samples [43]. For this reason, four methods of assessing antioxidants were used to study the antioxidant capacity of FPJ (Table 1).

The antioxidant activity of FPJ determined by the DDPH radical scavenging assay is shown in Table 3. The DPPH radical scavenging activities of FPJA decreased significantly after the fermentation process $(p<0.05)$, and the inhibition decreased from $81.90 \%$ to $55.60 \%$. The DPPH radical scavenging activity of FPJP ranged from $77.39 \%$ to $86.25 \%$, and the inhibition increased by $4.63 \%$. A similar change in the DPPH radical scavenging has been reported in other studies [44, 45]. The inhibition of FPJ showed that for both cultures there was $>50 \%$ of radical scavenging activity after $48 \mathrm{~h}$ of fermentation.

The results of the ABTS radical scavenging assays are shown in Table 3 . The ABTS radical scavenging activity of FPJA decreased significantly after $48 \mathrm{~h}$ fermentation $(p<$ 0.05 ). In contrast, the ABTS radical scavenging activity of FPJP tended to increase after fermentation, although no significant difference was observed. In both samples, the inhibition remained $>80 \%$ after the fermentation. Kim et al. [46] reported that fermented potato juices with Lactobacillus casei have a similar change in ABTS radical scavenging activity.

Similarly, the FRAP and CUPRAC values in FPJA decreased significantly after the $48 \mathrm{~h}$ fermentation period $(p<0.05)$ (Table 3). Hence, FRAP decreased by $20.60 \%$ (decrease from 5.68 to $4.51 \mathrm{mM} \mathrm{FeSO}_{4}$ ) and CUPRAC decreased by $6.45 \%$ (decreasing from 1.24 to $1.16 \mathrm{mM}$ trolox). The FRAP and CUPRAC values of FPJP increased slightly after the $48 \mathrm{~h}$ fermentation period $(p<0.05)$ (Table 3$)$. Hence, FRAP increased from 5.54 to $5.74 \mathrm{mM} \mathrm{FeSO}_{4}$ (n.s.), and CUPRAC increased from 1.26 to $1.57 \mathrm{mM}$ trolox $(p<$ 0.05).

Both strains have the same pattern for the content of antioxidant compounds. We observed that the total phenolic content of both strains had maximal values at 30 hours and then decreased (Table 1). The reasons for the decrease in the phenolic compounds in the papaya juices during probiotics fermentation likely include their precipitation or oxidation during the process, the combination or adsorption of phenolic compounds with solids, proteins, or even yeasts, and polymerization, all of which results in important losses of these compounds [47]. In contrast, the total flavonoids content of both strains increased. This could be explained by enzymatic degradation and by acids produced by the strain facilitating the release of phenolics and flavanones from their complexed forms in dietary fibre into freely soluble forms by the fermenting microorganism [12, 48]. Similar results were observed in the study of Kantachote et al. [49] who fermented coconut water with Lactobacillus plantarum DW12. There was a significant decrease in the total carotenoid content and vitamin $\mathrm{C}$ of papaya juices after fermentation by the two cultures $(p<0.05)$. The reason for the decreased total carotenoid content and vitamin $\mathrm{C}$ is that carotenoids and vitamin $\mathrm{C}$ are easily oxidized at high fermentation temperatures [50, 51].

In recent years, many scholars have become concerned about the antioxidant activity of fermented foods. Ohata et al. [52] studied fermented meat sauce, observing an increase in the DPPH radical scavenging activity. Simsek et al. [53] studied fermented vegetable juices but found no significant difference between the DPPH radical scavenging activity of fermented and unfermented vegetable juices. Nazzaro et al. [54] showed a decrease in the DPPH radical scavenging activity of fermented carrot juices with L. rhamnosus and also showed an increase in the DPPH radical scavenging activity of fermented carrot juices with L. bulgaricus after $48 \mathrm{~h}$. In addition, Gan et al. [55] reported that there is no change in the ABTS free radical scavenging capacity of fermented mung bean with $L$. plantarum WCFS1.

Overall, the two probiotic cultures showed different trends of antioxidant capacities. Li et al. [56] studied the effect of onion juice on the fermentation of milk by L. acidophilus, demonstrating that the antioxidant activity decreased significantly during the fermentation process, confirming that it was necessary to scavenge radicals for $L$. acidophilus growth. Hervert-Hernández et al. [57] studied the stimulatory role of grape pomace polyphenols on L. acidophilus growth and inferred that $L$. acidophilus may be able to use polyphenols possessing antioxidant functions as substrates. Our results are supported by the research of Ankolekar et al. [58], who observed a decrease in total phenolic content and antioxidant capacities throughout fermentation by L. acidophilus. Das and Goyal [59] reported that L. plantarum shows better antioxidant activity compared to L. acidophilus and can act as an antioxidative probiotic. L. plantarum fermentation broth has a strong reducing ability, $\mathrm{Fe}^{2+}$ chelating ability, and a variety of free radical scavenging abilities, as demonstrated by the work of Tang et al. [60]. All of these studies help to further illustrate our experimental results.

\subsection{The Organic Acid Contents of the Fermented Papaya} Juices. Lactic acid bacteria catabolize sugars via fermentation, leading to the formation of organic acids (including lactic acid, acetic acid), with ethanol as the final products [61, 62]. L. acidophilus is an obligately homofermentative bacteria (produces lactic acid as main metabolic product) while $L$. plantarum belongs to the facultatively homofermentative 
TABLE 3: Change in antioxidant activity of the fermented papaya juices.

\begin{tabular}{|c|c|c|c|c|}
\hline \multirow{2}{*}{ Fermentation time $(\mathrm{h})$} & \multicolumn{2}{|c|}{$\mathrm{DPPH}\left(\% \operatorname{Inh}^{\mathrm{A}}\right)$} & \multicolumn{2}{|c|}{ ABTS (\% Inh) } \\
\hline & L. acidophilus & L. plantarum & L. acidophilus & L. plantarum \\
\hline 0 & $81.9 \pm 1.2^{\mathrm{a}}$ & $79.5 \pm 0.7^{c}$ & $90.5 \pm 2.0^{\mathrm{a}}$ & $88.5 \pm 1.0^{\mathrm{a}}$ \\
\hline 6 & $77.1 \pm 2.9^{\mathrm{a}}$ & $77.4 \pm 0.4^{\mathrm{d}}$ & $86.8 \pm 3.1^{\mathrm{bc}}$ & $84.9 \pm 0.9^{\mathrm{d}}$ \\
\hline 12 & $78.8 \pm 0.4^{\mathrm{a}}$ & $78.5 \pm 0.4^{\mathrm{cd}}$ & $86.9 \pm 2.6^{b c}$ & $86.2 \pm 0.4^{\mathrm{c}}$ \\
\hline 18 & $78.0 \pm 0.4^{\mathrm{a}}$ & $81.4 \pm 0.5^{\mathrm{b}}$ & $87.5 \pm 0.8^{\mathrm{ab}}$ & $87.6 \pm 0.6^{\mathrm{abc}}$ \\
\hline 24 & $70.6 \pm 0.1^{\mathrm{b}}$ & $83.0 \pm 1.2^{\mathrm{b}}$ & $88.1 \pm 0.7^{\mathrm{ab}}$ & $86.9 \pm 1.1^{\mathrm{bc}}$ \\
\hline 30 & $66.9 \pm 3.96^{\mathrm{b}}$ & $86.3 \pm 1.1^{\mathrm{a}}$ & $89.8 \pm 0.9^{\mathrm{ab}}$ & $87.6 \pm 0.7^{\mathrm{ab}}$ \\
\hline 36 & $77.7 \pm 2.2^{\mathrm{a}}$ & $82.7 \pm 0.9^{b}$ & $90.6 \pm 1.3^{\mathrm{a}}$ & $87.9 \pm 0.6^{\mathrm{ab}}$ \\
\hline 42 & $60.8 \pm 5.7^{\mathrm{c}}$ & $83.5 \pm 1.7^{\mathrm{b}}$ & $86.9 \pm 0.7^{\mathrm{c}}$ & $88.8 \pm 0.7^{\mathrm{a}}$ \\
\hline 48 & $55.6 \pm 1.5^{\mathrm{d}}$ & $83.1 \pm 1.9^{\mathrm{b}}$ & $84.2 \pm 1.0^{\mathrm{c}}$ & $88.8 \pm 0.46^{\mathrm{a}}$ \\
\hline \multirow{2}{*}{ Fermentation time $(\mathrm{h})$} & \multicolumn{2}{|c|}{ FRAP $\left(\mathrm{mM} \mathrm{FeSO}_{4}\right)$} & \multicolumn{2}{|c|}{ CUPRAC (mM trolox) } \\
\hline & L. acidophilus & L. plantarum & L. acidophilus & L. plantarum \\
\hline 0 & $5.68 \pm 0.08^{\mathrm{a}}$ & $5.54 \pm 0.06^{\mathrm{cd}}$ & $1.24 \pm 0.04^{\mathrm{de}}$ & $1.26 \pm 0.02^{\mathrm{d}}$ \\
\hline 6 & $5.23 \pm 0.08^{\mathrm{bc}}$ & $5.30 \pm 0.11^{\mathrm{e}}$ & $1.29 \pm 0.012^{\mathrm{bc}}$ & $1.23 \pm 0.08^{\mathrm{d}}$ \\
\hline 12 & $5.71 \pm 0.06^{\mathrm{a}}$ & $5.54 \pm 0.16^{\mathrm{cd}}$ & $1.58 \pm 0.04^{\mathrm{a}}$ & $1.37 \pm 0.05^{\mathrm{c}}$ \\
\hline 18 & $5.24 \pm 0.16^{\mathrm{bc}}$ & $5.73 \pm 0.07^{\mathrm{abc}}$ & $1.34 \pm 0.03^{\mathrm{c}}$ & $1.44 \pm 0.02^{\mathrm{c}}$ \\
\hline 24 & $5.00 \pm 0.08^{\mathrm{cd}}$ & $5.87 \pm 0.07^{\mathrm{a}}$ & $1.27 \pm 0.03^{\mathrm{d}}$ & $1.61 \pm 0.01^{\mathrm{ab}}$ \\
\hline 30 & $4.81 \pm 0.15^{\mathrm{d}}$ & $5.80 \pm 0.09^{\mathrm{ab}}$ & $1.21 \pm 0.03^{\mathrm{de}}$ & $1.43 \pm 0.03^{\mathrm{c}}$ \\
\hline 36 & $5.33 \pm 0.17^{\mathrm{b}}$ & $5.63 \pm 0.14^{\mathrm{bc}}$ & $1.52 \pm 0.04^{\mathrm{b}}$ & $1.55 \pm 0.01^{\mathrm{b}}$ \\
\hline 42 & $5.11 \pm 0.12^{b c}$ & $5.38 \pm 0.13^{\mathrm{de}}$ & $1.27 \pm 0.03^{\mathrm{d}}$ & $1.68 \pm 0.16^{\mathrm{a}}$ \\
\hline 48 & $4.51 \pm 0.16^{\mathrm{e}}$ & $5.74 \pm 0.17^{\mathrm{abc}}$ & $1.16 \pm 0.06^{\mathrm{f}}$ & $1.57 \pm 0.02^{\mathrm{ab}}$ \\
\hline
\end{tabular}

Values are expressed as the mean $\pm \mathrm{SD}$. Values with different letters $(\mathrm{a} \sim \mathrm{f})$ in the same column are significantly different at $p<0.05$. A, inhibition.

TABLE 4: Changes in organic acid of the fermented papaya juices.

\begin{tabular}{|c|c|c|c|}
\hline Organic acids & Papaya juice $(\mathrm{mg} / 100 \mathrm{~mL})$ & $\begin{array}{l}\text { Fermented } 48 \mathrm{~h} \text { with L. acidophilus } \\
(\mathrm{mg} / 100 \mathrm{~mL})\end{array}$ & Fermented $48 \mathrm{~h}$ with L. plantarum $(\mathrm{mg} / 100 \mathrm{~mL})$ \\
\hline Lactic acid & $266 \pm 3^{b}$ & $543 \pm 68^{\mathrm{a}}$ & $571 \pm 32^{\mathrm{a}}$ \\
\hline Oxalic acid & $85.7 \pm 5.6^{\mathrm{a}}$ & $78.5 \pm 7.2^{\mathrm{a}}$ & $80.9 \pm 7.6^{\mathrm{a}}$ \\
\hline Tartaric acid & $0.36 \pm 0.03^{\mathrm{a}}$ & $0.10 \pm 0.02^{\mathrm{c}}$ & $0.16 \pm 0.02^{\mathrm{b}}$ \\
\hline Formic acid & $8.81 \pm 0.41^{b}$ & $20.94 \pm 4.10^{\mathrm{a}}$ & $18.42 \pm 2.08^{\mathrm{a}}$ \\
\hline Pyruvic acid & $0.55 \pm 0.05^{\mathrm{b}}$ & $1.13 \pm 0.15^{\mathrm{a}}$ & $1.20 \pm 0.11^{\mathrm{a}}$ \\
\hline Malic acid & $53.2 \pm 2.8^{\mathrm{b}}$ & $77.6 \pm 3.5^{\mathrm{a}}$ & $74.2 \pm 2.0^{\mathrm{a}}$ \\
\hline Acetic acid & $2.34 \pm 0.13^{\mathrm{c}}$ & $3.86 \pm 0.38^{\mathrm{b}}$ & $6.19 \pm 0.92^{\mathrm{a}}$ \\
\hline $\begin{array}{l}\text { Total organic } \\
\text { acid }\end{array}$ & 416 & 725 & 752 \\
\hline
\end{tabular}

Values are expressed as the mean $\pm \mathrm{SD}$. Values with different letters $(\mathrm{a} \sim \mathrm{c})$ in the same row are significantly different at $p<0.05$

group (produces lactic acid and other products such as acetic acid) [63]. These organic acids are important secondary carbon sources for numerous microbial genera that proliferate during food fermentation. The fermentation of papaya juices resulted in a significant change in the composition of the organic acids (Table 4), and the changes in organic acids between the two cultures were similar. Lactic acid, formic acid, pyruvic acid, malic acid, and acetic acid were significantly increased after fermentation $(p<0.05)$. Lactic acid was the most abundant organic acid formed after fermentation, with L. plantarum producing $571.29 \mathrm{mg} / 100 \mathrm{~mL}$ of lactic acid. L. plantarum produced more acetic than L. acidophilus $(6.19$ versus $3.86 \mathrm{mg} / 100 \mathrm{~mL})$. Oxalic acid did not change significantly throughout the fermentation process $(p<0.05)$. Tartaric acid, which may be used for microbial metabolism during the fermentation process, decreased significantly $(p<0.05)$ during fermentation, more with $L$. acidophilus ( 0.36 to $0.10 \mathrm{mg} / 100 \mathrm{~mL}$ ) than with L. plantarum $(0.16 \mathrm{mg} / 100 \mathrm{~mL})$. Tofalo et al. [64] reported that the content of lactic acid and acetic acid increased after fermented raw milk cheese with mesophilic lactobacilli and lactococci, which is similar to our results. In contrast, Yang et al. [65] observed a decrease in the content of malic acid and acetic acid in soymilk fermented with Bifidobacterium and Streptococci strains. Lee et al. [66] reported that the acetic acid increased and citric acid remained essentially unchanged throughout the fermentation in papaya wine fermented with three Williopsis saturnus yeasts, which is similar to our 
results. However, malic acid had a different trend in both fermentation processes.

3.4. Volatile Composition of Papaya Juices before and after Fermentation. Volatile components of various papaya cultivars have been widely studied by many scholars. More than 300 different aroma compounds have been identified in papaya fruits. Esters and alcohols are the main aroma components of papaya [67]. Various volatile components, including acids, alcohols, esters, aldehydes, ketones, and phenols, were detected in papaya juice before and after fermentation (Table 5). The volatiles present in papaya juices changed significantly after fermentation, and some differed between the two cultures.

Among the volatile acids identified, acetic acid and 3methyl-butanoic acid were the only two volatile acids produced by both cultures. 2-Methyl-propanoic acid was newly produced by $L$. plantarum.

Alcohols were the most abundant key volatiles extracted from the fermented papaya juices. The alcohols primarily consisted of ethanol, 3-methyl-1-butanol, and linalool. Some species in the Lactobacillus genus has the ability to produce ethanol, having alcohol dehydrogenase enzymes that can convert acetaldehyde into ethanol [68]. 3-Methyl-1-butanol has a pleasant aroma and is a major volatile compound of cheese. The metabolic pathway for the production of 3-methyl-butanol is the catabolism of amino-acids [69]. Globally, L. plantarum produced more alcohols than $L$. acidophilus. In studies of the volatile components of many varieties of papaya, linalool is one of the key aromatic compounds contributors in papaya fruit [70].

Among the major volatile compounds identified, the ester compounds are the most common. A total of 25 esters were identified in papaya juice before and after fermentation (Table 5). Pino [71] reported that esters were the primary class of volatile chemical compounds in papaya fruit. Acetate esters are formed by alcohol acetyltransferases from the reaction between acetyl-CoA and alcohols. Most volatile esters can enhance fruit flavor, especially ethyl acetate [72]. A high level of ethyl acetate and butanoic acid ethyl ester (pineapple fragrance) was produced by the two cultures (Table 5).

Ketones and lactones were the next most diverse group of volatile compounds in papaya juices, both before and after fermentation (Table 5). As expected, acetone, 2-butanone, acetoin, and 6-methyl-5-hepten2 -one were dominant volatile compounds. Acetone and 2-butanone have pungent odors, and their concentrations decreased after fermentation. In contrast, the quantity of acetoin (3-hydroxy-2-butanone), which has a milk aroma, increased throughout the fermentation process. Acetoin was observed to be produced from the metabolism of citrate [73]. 2-Heptanone, 1-hydroxy-2-propanone, 2-hydroxy-3-pentanone, 2-nonanone, 2-dodecanone, and 2 -tetradecanone were also produced after fermentation. They were likely derived from the $\beta$-oxidation of saturated free fatty acids and the further decarboxylation of $\beta$-ketoacids [74].
Melgarejo et al. [75] observed a negative relationship between juice quality and a high concentration of aldehydes. Aldehydes are easily reduced to alcohols or oxidized to acids in food matrices, especially in the presence of microbial activity [76]. The aldehydes became more abundant after fermentation. L. plantarum produced more new aldehydes than $L$. acidophilus throughout the fermentation process. Acetaldehyde and benzaldehyde were present at high levels in both FPJA and FPJP. It has been reported that benzaldehyde can provide ideal sensory properties, such as almonds, cherries, and sweetness [77]. Volatile phenols were also detected in the papaya juice before and after fermentation, and 2,4-ditert-butylphenol was the main volatile phenol detected in the papaya juices (Table 5 ).

In summary, a large number of volatiles were identified in papaya beverages before and after fermentation. We observed that the aroma components were similar after fermentation but in different proportions. Their contribution to the final flavor of beverages is being further studied. Lee et al. [25] reported that, in papaya wine fermented with Williopsis saturnus var. mrakii NCYC 2251, a wide range of volatile compounds were produced during fermentation including acids, alcohols, esters, and aldehydes with esters being the most abundant volatile compounds produced. In our study, volatile compounds have similar results with papaya wine, also esters being the most abundant volatile compounds in papaya juices. The volatile profiles given by $L$. acidophilus and L. plantarum were quite similar, although more alcohols and aldehydes were globally found with $L$. plantarum.

\section{Conclusion}

The present study investigated the use of papaya beverages as the main substrate for fermentation by two lactic acid bacteria, and a strain more suitable for fermentation was selected by comparing the different physicochemical properties of fermentation. The results show that, during papaya juice fermentation, both strains produced a large amount of volatiles with generally similar changes. However, the $\mathrm{pH}$ decrease was 0.05 units less with $L$. acidophilus than with $L$. plantarum which was consistent with the organic acid contents, especially lactic acid. This shows that $L$. plantarum is more suitable for growth and stronger acid production capacity is based on papaya juice. Antioxidant activity tended to differ between L. acidophilus and L. plantarum. The antioxidant capacity of FPJA decreased significantly, whereas the antioxidant capacity of FPJP increased after fermentation, showing a better oxidation resistance. Through comparisons of the $\mathrm{pH}$, organic acids, antioxidant components, and volatile compounds, especially the change in antioxidant activity, it was found that $L$. plantarum is more suitable for the production of fermented papaya beverages. It is worth noting that both FPJA and FPJP produce a large number of flavonoids, which has become a hot research topic in recent years because of its pharmacological activity. We will conduct additional relevant tests to study the efficacy of LAB fermentation of papaya, such as the effect of weight loss and lipid lowering. In a word, fermented papaya juice could be a novel probiotic beverage for consumers. 
TABLE 5: Major volatile compounds and relative peak area in papaya juices before and after $48 \mathrm{~h}$ fermentation.

\begin{tabular}{|c|c|c|c|c|c|}
\hline Volatile compounds & $\mathrm{RT}$ & RI & $\begin{array}{c}\text { Papaya juice } \\
\mathrm{PA} \times 10^{6}\end{array}$ & $\begin{array}{c}\text { FPJA } 48 \mathrm{~h} \\
\mathrm{PA} \times 10^{6}\end{array}$ & $\begin{array}{l}\text { FPJP } 48 \mathrm{~h} \\
\mathrm{PA} \times 10^{6}\end{array}$ \\
\hline \multicolumn{6}{|l|}{ Acids } \\
\hline Acetic acid & 19.36 & 1444 & $319.80 \pm 17.04^{\mathrm{c}}$ & $1809.78 \pm 80.37^{\mathrm{a}}$ & $753.41 \pm 20.64^{\mathrm{b}}$ \\
\hline Propanoic acid & 21.81 & 1537 & $23.48 \pm 3.56^{\mathrm{a}}$ & - & - \\
\hline 2-Methyl-propanoic acid & 22.56 & 1567 & - & - & $28.15 \pm 1.55^{\mathrm{a}}$ \\
\hline Butanoic acid & 23.94 & 1623 & $157.19 \pm 9.48^{\mathrm{b}}$ & $195.87 \pm 11.58^{\mathrm{a}}$ & $195.54 \pm 8.36^{\mathrm{a}}$ \\
\hline 3-Methyl-Butanoic acid & 24.97 & 1666 & - & $55.83 \pm 2.64^{\mathrm{b}}$ & $228.29 \pm 11.57^{\mathrm{a}}$ \\
\hline 2-Methyl-Butanoic acid & 25.00 & 1668 & - & - & $199.49 \pm 20.60^{\mathrm{a}}$ \\
\hline Hexanoic acid & 28.93 & 1845 & $99.80 \pm 5.94^{\mathrm{a}}$ & - & - \\
\hline 2-Ethyl-Hexanoic acid & 31.15 & 1953 & $17.54 \pm 1.21^{\mathrm{a}}$ & $16.76 \pm 1.75^{\mathrm{a}}$ & - \\
\hline Octanoic acid & 33.33 & 2063 & $105.10 \pm 6.35^{\mathrm{b}}$ & $104.05 \pm 5.36^{\mathrm{b}}$ & $147.15 \pm 9.17^{\mathrm{a}}$ \\
\hline Nonanoic acid & 35.45 & 2174 & $25.18 \pm 2.81^{b}$ & $32.54 \pm 1.27^{\mathrm{a}}$ & - \\
\hline n-Decanoic acid & 37.44 & 2281 & $22.54 \pm 1.38^{\mathrm{a}}$ & - & - \\
\hline \multicolumn{6}{|l|}{ Alcohols } \\
\hline Ethanol & 4.28 & 930 & $475.70 \pm 29.14^{\mathrm{c}}$ & $5070.47 \pm 156.45^{\mathrm{a}}$ & $3306.28 \pm 180.67^{\mathrm{b}}$ \\
\hline 1-Propanol & 7.11 & 1043 & - & $15.78 \pm 2.36^{\mathrm{b}}$ & $23.35 \pm 1.48^{\mathrm{a}}$ \\
\hline 2-Methyl-1-propanol & 9.14 & 1113 & - & - & $43.67 \pm 3.50^{\mathrm{a}}$ \\
\hline 1-Butanol & 10.71 & 1160 & - & $7.00 \pm 0.27^{\mathrm{b}}$ & $27.01 \pm 2.36^{\mathrm{a}}$ \\
\hline 1-Penten-3-ol & 11.14 & 1173 & $8.86 \pm 0.35^{\mathrm{a}}$ & $2.62 \pm 0.13^{c}$ & $3.78 \pm 0.05^{\mathrm{b}}$ \\
\hline 3-Methyl-1-butanol & 12.66 & 1219 & $12.45 \pm 1.50^{\mathrm{c}}$ & $1107.19 \pm 42.15^{\mathrm{b}}$ & $1542.59 \pm 37.75^{\mathrm{a}}$ \\
\hline 3-Methyl-3-buten-1-ol & 13.84 & 1255 & - & - & $15.17 \pm 2.58^{\mathrm{a}}$ \\
\hline 1-Pentanol & 13.96 & 1259 & $9.53 \pm 1.32^{\mathrm{b}}$ & - & $18.93 \pm 1.86^{\mathrm{a}}$ \\
\hline Prenol & 16.00 & 1325 & - & $10.01 \pm 0.83^{\mathrm{a}}$ & $12.64 \pm 2.87^{\mathrm{a}}$ \\
\hline 3-Pentanol & 16.43 & 1340 & - & $29.02 \pm 1.48^{\mathrm{b}}$ & $46.42 \pm 3.40^{\mathrm{a}}$ \\
\hline 1-Hexanol & 16.95 & 1357 & $12.44 \pm 2.74^{\mathrm{c}}$ & $38.82 \pm 1.39^{\mathrm{b}}$ & $51.03 \pm 3.65^{\mathrm{a}}$ \\
\hline 1-Heptanol & 19.77 & 1459 & $8.50 \pm 0.46^{\mathrm{a}}$ & $5.92 \pm 0.27^{\mathrm{c}}$ & $7.43 \pm 0.24^{\mathrm{b}}$ \\
\hline 2-Ethyl-1-hexanol & 20.69 & 1493 & $836.35 \pm 32.85^{\mathrm{a}}$ & - & - \\
\hline Linalool & 22.04 & 1546 & $944.70 \pm 74.91^{\mathrm{a}}$ & $600.17 \pm 27.61^{c}$ & $766.51 \pm 30.67^{\mathrm{b}}$ \\
\hline 1-Octanol & 22.39 & 1560 & $22.64 \pm 3.67^{c}$ & $56.57 \pm 3.40^{\mathrm{a}}$ & $33.45 \pm 1.42^{\mathrm{b}}$ \\
\hline 1-Nonanol & 24.82 & 1660 & $40.83 \pm 7.36^{\mathrm{a}}$ & - & $39.66 \pm 5.82^{\mathrm{a}}$ \\
\hline 1-Decanol & 27.15 & 1762 & - & $42.84 \pm 4.16^{\mathrm{a}}$ & $17.81 \pm 1.27^{\mathrm{b}}$ \\
\hline Geraniol & 28.94 & 1845 & - & - & $97.05 \pm 7.43^{\mathrm{a}}$ \\
\hline Benzyl alcohol & 29.44 & 1869 & $19.58 \pm 0.97^{\mathrm{c}}$ & $90.93 \pm 7.34^{\mathrm{b}}$ & $133.85 \pm 8.61^{\mathrm{a}}$ \\
\hline Phenylethyl alcohol & 30.20 & 1905 & - & $117.29 \pm 6.97^{\mathrm{b}}$ & $222.19 \pm 21.85^{\mathrm{a}}$ \\
\hline Nerolidol & 32.83 & 2037 & - & - & $2.12 \pm 0.03^{\mathrm{a}}$ \\
\hline \multicolumn{6}{|l|}{ Aldehydes } \\
\hline Acetaldehyde & 2.05 & 6956 & $370.89 \pm 23.64^{\mathrm{a}}$ & $287.47 \pm 12.34^{\mathrm{b}}$ & $368.09 \pm 15.28^{\mathrm{a}}$ \\
\hline Pentanal & 5.19 & 970 & - & - & $84.82 \pm 6.34$ \\
\hline Hexanal & 8.29 & 1085 & - & - & $12.47 \pm 0.72$ \\
\hline 2-Methyl-2-heptenal & 10.11 & 1142 & $20.95 \pm 1.78^{\mathrm{a}}$ & - & $21.67 \pm 1.81^{\mathrm{a}}$ \\
\hline Heptanal & 11.66 & 1188 & - & - & $24.97 \pm 0.94^{\mathrm{a}}$ \\
\hline Octanal & 14.93 & 1289 & - & - & $30.47 \pm 4.35^{\mathrm{a}}$ \\
\hline 2,6-Dimethyl-5-heptenal & 16.80 & 1352 & $2.79 \pm 0.08^{\mathrm{a}}$ & - & - \\
\hline Nonanal & 17.96 & 1392 & $104.87 \pm 2.65^{\mathrm{b}}$ & $49.84 \pm 10.45^{\mathrm{c}}$ & $153.20 \pm 6.45^{\mathrm{a}}$ \\
\hline Benzaldehyde & 21.24 & 1514 & $27.89 \pm 1.84^{\mathrm{b}}$ & $27.53 \pm 1.63^{b}$ & $57.56 \pm 2.61^{\mathrm{a}}$ \\
\hline Dodecanal & 25.90 & 1706 & - & $9.13 \pm 0.27^{\mathrm{b}}$ & $19.50 \pm 0.88^{\mathrm{a}}$ \\
\hline 2,4-Dimethyl-benzaldehyde & 28.02 & 1801 & - & $3.58 \pm 0.80^{\mathrm{b}}$ & $26.92 \pm 1.47^{\mathrm{a}}$ \\
\hline
\end{tabular}


TABLE 5: Continued.

\begin{tabular}{|c|c|c|c|c|c|}
\hline Volatile compounds & RT & RI & $\begin{array}{c}\text { Papaya juice } \\
\mathrm{PA} \times 10^{6}\end{array}$ & $\begin{array}{l}\text { FPJA } 48 \mathrm{~h} \\
\mathrm{PA} \times 10^{6}\end{array}$ & $\begin{array}{l}\text { FPJP } 48 \mathrm{~h} \\
\mathrm{PA} \times 10^{6}\end{array}$ \\
\hline \multicolumn{6}{|l|}{ Esters } \\
\hline Acetic, methyl ester & 2.74 & 820 & $6.97 \pm 0.07^{\mathrm{b}}$ & $4.66 \pm 0.26^{\mathrm{c}}$ & $11.62 \pm 0.62^{\mathrm{a}}$ \\
\hline Acetic, ethyl ester & 3.38 & 881 & $3.93 \pm 0.12^{\mathrm{b}}$ & $42.89 \pm 3.90^{\mathrm{a}}$ & $37.62 \pm 3.55^{\mathrm{a}}$ \\
\hline Butanoic acid, methyl ester & 5.41 & 979 & $11.35 \pm 0.58^{\mathrm{a}}$ & $3.35 \pm 0.21^{\mathrm{c}}$ & $7.23 \pm 0.74^{\mathrm{b}}$ \\
\hline Butanoic acid, ethyl ester & 6.96 & 1038 & - & $35.88 \pm 1.54^{\mathrm{a}}$ & $18.37 \pm 0.93^{\mathrm{b}}$ \\
\hline Hexanoic acid, methyl ester & 11.77 & 1191 & $9.41 \pm 1.40^{\mathrm{a}}$ & - & $2.77 \pm 0.07^{\mathrm{b}}$ \\
\hline Hexanoic acid, ethyl ester & 13.31 & 1239 & - & $8.55 \pm 1.30^{\mathrm{a}}$ & - \\
\hline Thiocyanic acid, methyl ester & 14.22 & 1267 & $7.01 \pm 0.65^{\mathrm{a}}$ & $3.09 \pm 1.32^{\mathrm{b}}$ & $4.29 \pm 0.68^{\mathrm{b}}$ \\
\hline Acetic acid, 2-ethylhexyl ester & 17.75 & 1385 & $6.54 \pm 1.28^{\mathrm{a}}$ & $3.15 \pm 0.47^{\mathrm{b}}$ & $5.82 \pm 0.85^{\mathrm{a}}$ \\
\hline Octanoic acid, methyl ester & 17.89 & 1390 & $48.07 \pm 3.67^{\mathrm{a}}$ & $5.55 \pm 0.24^{\mathrm{c}}$ & $11.89 \pm 1.52^{\mathrm{b}}$ \\
\hline Octanoic acid, ethyl ester & 19.14 & 1436 & $9.88 \pm 0.42^{\mathrm{b}}$ & $16.59 \pm 1.37^{\mathrm{a}}$ & $10.12 \pm 0.73^{\mathrm{b}}$ \\
\hline n-Butyric acid 2-ethylhexyl ester & 21.44 & 1522 & $207.11 \pm 10.37^{\mathrm{c}}$ & $227.53 \pm 5.39^{b}$ & $255.75 \pm 6.74^{\mathrm{a}}$ \\
\hline Decanoic acid, methyl ester & 23.23 & 1593 & $75.10 \pm 3.43^{\mathrm{a}}$ & $14.32 \pm 1.50^{\mathrm{b}}$ & $10.17 \pm 0.64^{\mathrm{c}}$ \\
\hline Decanoic acid, ethyl ester & 24.27 & 1637 & $9.93 \pm 0.27^{\mathrm{b}}$ & $13.59 \pm 0.64^{\mathrm{a}}$ & $9.30 \pm 0.55^{\mathrm{bc}}$ \\
\hline Hexanoic acid, 2-ethylhexyl ester & 25.97 & 1709 & $60.19 \pm 5.39^{\mathrm{a}}$ & $50.84 \pm 3.276^{\mathrm{b}}$ & $60.42 \pm 3.46^{\mathrm{a}}$ \\
\hline Dodecanoic acid, methyl ester & 27.98 & 1799 & $33.23 \pm 1.27^{\mathrm{a}}$ & $20.09 \pm 2.35^{\mathrm{b}}$ & $9.92 \pm 3.57^{\mathrm{c}}$ \\
\hline Dodecanoic acid, ethyl ester & 28.88 & 1842 & $2.75 \pm 0.06^{\mathrm{b}}$ & $4.54 \pm 0.61^{\mathrm{a}}$ & $2.62 \pm 0.24^{\mathrm{b}}$ \\
\hline Tetradecanoic, methyl ester & 32.28 & 2009 & $36.71 \pm 1.85^{\mathrm{a}}$ & $21.28 \pm 3.65^{\mathrm{b}}$ & - \\
\hline Myristoleate, methyl ester & 33.02 & 2047 & $13.54 \pm 0.64^{\mathrm{a}}$ & - & - \\
\hline Tetradecanoic acid, ethyl ester & 33.06 & 2049 & - & $9.64 \pm 0.15^{\mathrm{a}}$ & - \\
\hline Benzoic acid, 2-ethylhexyl ester & 35.38 & 2171 & $24.12 \pm 1.34^{\mathrm{a}}$ & $21.47 \pm 0.76^{\mathrm{b}}$ & $19.18 \pm 0.51^{c}$ \\
\hline Hexadecanoic acid, methyl ester & 36.22 & 2216 & $6.72 \pm 2.68^{\mathrm{a}}$ & - & - \\
\hline Dodecanoic acid, ethyl ester & 36.90 & 2252 & - & $8.71 \pm 0.34^{\mathrm{a}}$ & - \\
\hline 9-Hexadecenoate, ethyl ester & 37.37 & 2277 & $37.39 \pm 6.37^{\mathrm{a}}$ & $7.61 \pm 0.69^{b}$ & - \\
\hline 1,2-Benzenedicarboxylic acid, bis(2-methylpropyl) ester & 41.66 & 2506 & - & $32.24 \pm 2.31^{\mathrm{a}}$ & $23.12 \pm 3.16^{\mathrm{b}}$ \\
\hline Dibutyl phthalate & 44.09 & 2636 & - & $12.25 \pm 3.20^{\mathrm{a}}$ & $9.71 \pm 0.91^{\mathrm{b}}$ \\
\hline \multicolumn{6}{|l|}{ Ketones and lactones } \\
\hline Acetone & 2.62 & 809 & $483.80 \pm 32.45^{\mathrm{a}}$ & $411.31 \pm 16.38^{\mathrm{b}}$ & $410.72 \pm 11.27^{\mathrm{b}}$ \\
\hline 2-Butanone & 3.55 & 897 & $234.15 \pm 11.84^{\mathrm{a}}$ & $146.93 \pm 14.75^{\mathrm{b}}$ & $166.03 \pm 20.84^{\mathrm{b}}$ \\
\hline 2,3-Butanedione & 5.16 & 968 & $107.29 \pm 6.87^{\mathrm{a}}$ & $113.63 \pm 8.55^{\mathrm{a}}$ & $84.82 \pm 6.98^{\mathrm{b}}$ \\
\hline 2-Heptanone & 11.61 & 1187 & - & - & $25.26 \pm 5.27^{\mathrm{a}}$ \\
\hline Acetoin & 14.79 & 1285 & $752.58 \pm 55.28^{\mathrm{c}}$ & $2804.69 \pm 96.38^{b}$ & $1688.42 \pm 67.38^{\mathrm{a}}$ \\
\hline 1-Hydroxy-2-Propanone & 15.15 & 1296 & - & - & $4.35 \pm 0.76^{\mathrm{a}}$ \\
\hline 6-Methyl-5-Hepten-2-one & 16.36 & 1337 & $276.58 \pm 15.94^{\mathrm{a}}$ & $139.80 \pm 23.70^{\mathrm{b}}$ & $79.95 \pm 11.56^{\mathrm{c}}$ \\
\hline 2-Hydroxy-3-pentanone & 16.91 & 1356 & - & $38.81 \pm 2.85^{\mathrm{b}}$ & $51.03 \pm 3.44^{\mathrm{a}}$ \\
\hline 2-Nonanone & 17.86 & 1389 & - & $20.28 \pm 1.74^{\mathrm{a}}$ & - \\
\hline 3-(Hydroxymethyl)-2-Nonanone & 17.92 & 1391 & $48.07 \pm 2.95^{\mathrm{a}}$ & $50.78 \pm 3.64^{\mathrm{a}}$ & $4.79 \pm 0.12^{\mathrm{b}}$ \\
\hline 2-Octanone & 23.30 & 1596 & $5.60 \pm 0.14^{c}$ & $20.43 \pm 1.38^{\mathrm{a}}$ & $11.85 \pm 1.30^{\mathrm{b}}$ \\
\hline 2-Dodecanone & 28.12 & 1806 & - & $5.63 \pm 0.47^{\mathrm{a}}$ & - \\
\hline 2-Tetradecanone & 28.12 & 1806 & - & - & $8.03 \pm 1.14$ \\
\hline \multicolumn{6}{|l|}{ Phenols } \\
\hline 2,6-Bis(1,1-dimethylethyl)-4-(1-oxopropyl)phenol & 30.52 & 1921 & - & $14.33 \pm 0.92^{\mathrm{a}}$ & $14.22 \pm 1.17^{\mathrm{a}}$ \\
\hline Phenol & 31.98 & 1994 & - & $43.80 \pm 4.51^{\mathrm{a}}$ & $26.82 \pm 3.95^{\mathrm{b}}$ \\
\hline 2,4-Di-tert-butylphenol & 37.78 & 2299 & $84.52 \pm 6.87^{\mathrm{a}}$ & $45.58 \pm 3.63^{\mathrm{b}}$ & $36.54 \pm 3.29^{c}$ \\
\hline 2,6-Di-tert-butyl-4-methoxyphenol & 46.52 & 2765 & $5.44 \pm 1.23^{\mathrm{a}}$ & - & - \\
\hline
\end{tabular}

Values are expressed as the mean \pm SD. Values with different letters $(\mathrm{a} \sim \mathrm{c})$ in the same row are significantly different at $p<0.05$. RT, retention time; RI, retention index; PA, peak area; RPA, ratio of peak area; “-”, not detected. 


\section{Conflicts of Interest}

The authors declare that they have no conflicts of interest.

\section{Acknowledgments}

This investigation was supported by the Production and Research Integration of Special Projects of Hainan Province (CXY20150032) and the Natural Science Fund of Hainan Province of China (317002).

\section{References}

[1] S. J. Rhee, J.-E. Lee, and C.-H. Lee, "Importance of lactic acid bacteria in Asian fermented foods," Microbial Cell Factories, vol. 10, no. 1, article no. S5, 2011.

[2] F. Altay, F. Karbancioglu-Güler, C. Daskaya-Dikmen, and D. Heperkan, "A review on traditional turkish fermented nonalcoholic beverages: microbiota, fermentation process and quality characteristics," International Journal of Food Microbiology, vol. 167, no. 1, pp. 44-56, 2013.

[3] A. Czyzowska, E. Klewicka, and Z. Libudzisz, "The influence of lactic acid fermentation process of red beet juice on the stability of biologically active colorants," European Food Research and Technology, vol. 223, no. 1, pp. 110-116, 2006.

[4] R. Sõukand, A. Pieroni, M. Biró et al., "An ethnobotanical perspective on traditional fermented plant foods and beverages in Eastern Europe," Journal of Ethnopharmacology, vol. 170, no. 1, pp. 284-296, 2015.

[5] I. Salmerón, K. Thomas, and S. S. Pandiella, "Effect of potentially probiotic lactic acid bacteria on the physicochemical composition and acceptance of fermented cereal beverages," Journal of Functional Foods, vol. 15, pp. 106-115, 2015.

[6] B. Bigliardi and F. Galati, "Innovation trends in the food industry: the case of functional foods," Trends in Food Science \& Technology, vol. 31, no. 2, pp. 118-129, 2013.

[7] C. Puerari, K. T. Magalhães, and R. F. Schwan, "New cocoa pulpbased kefir beverages: Microbiological, chemical composition and sensory analysis," Food Research International, vol. 48, no. 2, pp. 634-640, 2012.

[8] F. C. Prado, J. L. Parada, A. Pandey, and C. R. Soccol, “Trends in non-dairy probiotic beverages," Food Research International, vol. 41, no. 2, pp. 111-123, 2008.

[9] A. P. Mestry, A. S. Mujumdar, and B. N. Thorat, "Optimization of spray drying of an innovative functional food: Fermented mixed juice of carrot and watermelon," Drying Technology, vol. 29, no. 10, pp. 1121-1131, 2011.

[10] K. Y. Yoon, E. E. Woodams, and Y. D. Hang, "Probiotication of tomato juice by lactic acid bacteria," Journal of Microbiology, vol. 42, no. 4, pp. 315-318, 2004.

[11] A. L. F. Pereira, T. C. Maciel, and S. Rodrigues, "Probiotic beverage from cashew apple juice fermented with Lactobacillus casei," Food Research International, vol. 44, no. 5, pp. 1276-1283, 2011.

[12] K. Ghosh, M. Ray, A. Adak et al., "Role of probiotic Lactobacillus fermentum KKL1 in the preparation of a rice based fermented beverage," Bioresource Technology, vol. 188, pp. 161168, 2015.

[13] F. Leroy and L. de Vuyst, "Lactic acid bacteria as functional starter cultures for the food fermentation industry," Trends in Food Science \& Technology, vol. 15, no. 2, pp. 67-78, 2004.
[14] H. Lee, H. Yoon, Y. Ji et al., "Functional properties of Lactobacillus strains isolated from kimchi," International Journal of Food Microbiology, vol. 145, no. 1, pp. 155-161, 2011.

[15] R. Kumar, S. Grover, and V. K. Batish, "Hypocholesterolaemic effect of dietary inclusion of two putative probiotic bile salt hydrolase-producing Lactobacillus plantarum strains in Sprague-Dawley rats," British Journal of Nutrition, vol. 105, no. 4, pp. 561-573, 2011.

[16] S. Parvez, K. A. Malik, S. A. Ah Kang, and H.-Y. Kim, "Probiotics and their fermented food products are beneficial for health," Journal of Applied Microbiology, vol. 100, no. 6, pp. 11711185, 2006.

[17] D. Chen, X. Pang, J. Zhao et al., "Comparing the effects of high hydrostatic pressure and high temperature short time on papaya beverage," Innovative Food Science and Emerging Technologies, vol. 32, pp. 16-28, 2015.

[18] D. M. Rivera-Pastrana, E. M. Yahia, and G. A. GonzálezAguilar, "Phenolic and carotenoid profiles of papaya fruit (Carica papaya L.) and their contents under low temperature storage," Journal of the Science of Food and Agriculture, vol. 90, no. 14, pp. 2358-2365, 2010.

[19] P. Udomkun, M. Nagle, D. Argyropoulos, B. Mahayothee, S. Latif, and J. Müller, "Compositional and functional dynamics of dried papaya as affected by storage time and packaging material," Food Chemistry, vol. 196, pp. 712-719, 2016.

[20] R. Ming, S. Hou, Y. Feng et al., "The draft genome of the transgenic tropical fruit tree papaya (Carica papaya Linnaeus)," Nature, vol. 452, no. 7190, pp. 991-996, 2008.

[21] T. Kokila, P. S. Ramesh, and D. Geetha, "Biosynthesis of AgNPs using Carica Papaya peel extract and evaluation of its antioxidant and antimicrobial activities," Ecotoxicology and Environmental Safety, vol. 134, pp. 467-473, 2016.

[22] P. Udomkun, M. Nagle, B. Mahayothee, D. Nohr, A. Koza, and J. Müller, "Influence of air drying properties on non-enzymatic browning, major bio-active compounds and antioxidant capacity of osmotically pretreated papaya," LWT-Food Science and Technology, vol. 60, no. 2, pp. 914-922, 2015.

[23] J. P. Fabi, B. R. Cordenunsi, G. P. D. M. Barreto, A. Z. Mercadante, F. M. Lajolo, and J. R. O. Do Nascimento, "Papaya fruit ripening: Response to ethylene and 1-methylcyclopropene (1-MCP)," Journal of Agricultural and Food Chemistry, vol. 55, no. 15, pp. 6118-6123, 2007.

[24] C. M. Peres, C. Peres, A. Hernández-Mendoza, and F. X. Malcata, "Review on fermented plant materials as carriers and sources of potentially probiotic lactic acid bacteria - With an emphasis on table olives," Trends in Food Science \& Technology, vol. 26, no. 1, pp. 31-42, 2012.

[25] P.-R. Lee, B. Yu, P. Curran, and S.-Q. Liu, "Effect of fusel oil addition on volatile compounds in papaya wine fermented with Williopsis saturnus var. mrakii NCYC 2251," Food Research International, vol. 44, no. 5, pp. 1292-1298, 2011.

[26] P.-R. Lee, Y.-L. Ong, B. Yu, P. Curran, and S.-Q. Liu, "Profile of volatile compounds during papaya juice fermentation by a mixed culture of Saccharomyces cerevisiae and Williopsis saturnus," Food Microbiology, vol. 27, no. 7, pp. 853-861, 2010.

[27] R. Di Cagno, G. Minervini, C. G. Rizzello, M. De Angelis, and M. Gobbetti, "Effect of lactic acid fermentation on antioxidant, texture, color and sensory properties of red and green smoothies," Food Microbiology, vol. 28, no. 5, pp. 1062-1071, 2011. 
[28] A. A. N. Saqib and P. J. Whitney, "Differential behaviour of the dinitrosalicylic acid (DNS) reagent towards mono- and disaccharide sugars," Biomass \& Bioenergy, vol. 35, no. 11, pp. 4748-4750, 2011.

[29] V. M. Moo-Huchin, I. Estrada-Mota, R. Estrada-León et al., "Determination of some physicochemical characteristics, bioactive compounds and antioxidant activity of tropical fruits from Yucatan, Mexico," Food Chemistry, vol. 152, pp. 508-515, 2014.

[30] L. Z. C. M. de Sá, P. F. S. Castro, F. M. A. Lino et al., "Antioxidant potential and vasodilatory activity of fermented beverages of jabuticaba berry (Myrciaria jaboticaba)," Journal of Functional Foods, vol. 8, no. 1, pp. 169-179, 2014.

[31] P. Wu, G. Ma, N. Li, Q. Deng, Y. Yin, and R. Huang, "Investigation of in vitro and in vivo antioxidant activities of flavonoids rich extract from the berries of Rhodomyrtus tomentosa(Ait.) Hassk," Food Chemistry, vol. 173, pp. 194-202, 2015.

[32] J. M. Carbonell-Capella, M. Buniowska, M. J. Esteve, and A. Frígola, "Effect of Stevia rebaudiana addition on bioaccessibility of bioactive compounds and antioxidant activity of beverages based on exotic fruits mixed with oat following simulated human digestion," Food Chemistry, vol. 184, Article ID 17342, pp. 122-130, 2015.

[33] S. Li, Y. Zhao, L. Zhang et al., "Antioxidant activity of Lactobacillus plantarum strains isolated from traditional Chinese fermented foods," Food Chemistry, vol. 135, no. 3, pp. 1914-1919, 2012.

[34] M. Um, G.-J. Shin, and J.-W. Lee, "Extraction of total phenolic compounds from yellow poplar hydrolysate and evaluation of their antioxidant activities," Industrial Crops and Products, vol. 97, pp. 574-581, 2017.

[35] A. Morales-Soto, P. García-Salas, C. Rodríguez-Pérez et al., "Antioxidant capacity of 44 cultivars of fruits and vegetables grown in Andalusia (Spain)," Food Research International, vol. 58, pp. 35-46, 2014.

[36] E. Kondakçi, M. Özyürek, K. Güçlü, and R. Apak, "Novel prooxidant activity assay for polyphenols, vitamins $\mathrm{C}$ and e using a modified CUPRAC method," Talanta, vol. 115, pp. 583-589, 2013.

[37] L. Zou, Y.-Y. Hu, and W.-X. Chen, "Antibacterial mechanism and activities of black pepper chloroform extract," Journal of Food Science and Technology, vol. 52, no. 12, pp. 8196-8203, 2015.

[38] J. Zhao, H. Li, W. Xi et al., "Changes in sugars and organic acids in wolfberry (Lycium barbarum L.) fruit during development and maturation," Food Chemistry, vol. 173, pp. 718-724, 2015.

[39] P. Fuggate, C. Wongs-Aree, S. Noichinda, and S. Kanlayanarat, "Quality and volatile attributes of attached and detached 'Pluk Mai Lie' papaya during fruit ripening," Scientia Horticulturae, vol. 126, no. 2, pp. 120-129, 2010.

[40] L. W. Lee, M. W. Cheong, P. Curran, B. Yu, and S. Q. Liu, "Coffee fermentation and flavor - An intricate and delicate relationship," Food Chemistry, vol. 185, pp. 182-191, 2015.

[41] D. Klupsaite, G. Juodeikiene, D. Zadeike, E. Bartkiene, Z. Maknickiene, and G. Liutkute, "The influence of lactic acid fermentation on functional properties of narrow-leaved lupine protein as functional additive for higher value wheat bread," LWT- Food Science and Technology, vol. 75, pp. 180-186, 2017.

[42] L. M. R. Da Silva, E. A. T. De Figueiredo, N. M. P. S. Ricardo et al., "Quantification of bioactive compounds in pulps and byproducts of tropical fruits from Brazil," Food Chemistry, vol. 143, pp. 398-404, 2014.
[43] Y. Xiao, G. Xing, X. Rui et al., "Enhancement of the antioxidant capacity of chickpeas by solid state fermentation with Cordyceps militaris SN-18," Journal of Functional Foods, vol. 10, pp. 210-222, 2014.

[44] J. Yang, Y. Ji, H. Park et al., "Selection of functional lactic acid bacteria as starter cultures for the fermentation of Korean leek (Allium tuberosum Rottler ex Sprengel.)," International Journal of Food Microbiology, vol. 191, pp. 164-171, 2014.

[45] R. V. Malbaša, E. S. Lončar, J. S. Vitas, and J. M. ČanadanovićBrunet, "Influence of starter cultures on the antioxidant activity of kombucha beverage," Food Chemistry, vol. 127, no. 4, pp. 17271731, 2011.

[46] N. J. Kim, H. L. Jang, and K. Y. Yoon, "Potato juice fermented with Lactobacillus casei as a probiotic functional beverage," Food Science and Biotechnology, vol. 21, no. 5, pp. 1301-1307, 2012.

[47] B. Escudero-López, I. Cerrillo, G. Herrero-Martín et al., "Fermented orange juice: Source of higher carotenoid and flavanone contents," Journal of Agricultural and Food Chemistry, vol. 61, no. 37, pp. 8773-8782, 2013.

[48] R. Bhat, L. C. Suryanarayana, K. A. Chandrashekara, P. Krishnan, A. Kush, and P. Ravikumar, "Lactobacillus plantarum mediated fermentation of Psidium guajava L. fruit extract," Journal of Bioscience and Bioengineering, vol. 119, no. 4, pp. 430432, 2015.

[49] D. Kantachote, A. Ratanaburee, W. Hayisama-ae, A. Sukhoom, and T. Nunkaew, "The use of potential probiotic Lactobacillus plantarum DW12 for producing a novel functional beverage from mature coconut water," Journal of Functional Foods, vol. 32, pp. 401-408, 2017.

[50] B. S. Oladeji, C. T. Akanbi, and S. O. Gbadamosi, "Effects of fermentation on antioxidant properties of flours of a normal endosperm and quality protein maize varrieties," Journal of Food Measurement and Characterization, vol. 11, no. 3, pp. 11481158, 2017.

[51] S. K. Panda, S. K. Behera, X. Witness Qaku et al., "Quality enhancement of prickly pears (Opuntia sp.) juice through probiotic fermentation using Lactobacillus fermentum - ATCC 9338," LWT- Food Science and Technology, vol. 75, pp. 453-459, 2017.

[52] M. Ohata, S. Uchida, L. Zhou, and K. Arihara, "Antioxidant activity of fermented meat sauce and isolation of an associated antioxidant peptide," Food Chemistry, vol. 194, pp. 1034-1039, 2016.

[53] S. Simsek, S. N. El, A. Kancabas Kilinc, and S. Karakaya, "Vegetable and fermented vegetable juices containing germinated seeds and sprouts of lentil and cowpea," Food Chemistry, vol. 156, pp. 289-295, 2014.

[54] F. Nazzaro, F. Fratianni, A. Sada, and P. Orlando, "Synbiotic potential of carrot juice supplemented with Lactobacillus spp. and inulin or fructooligosaccharides," Journal of the Science of Food and Agriculture, vol. 88, no. 13, pp. 2271-2276, 2008.

[55] R.-Y. Gan, N. P. Shah, M.-F. Wang, W.-Y. Lui, and H. Corke, "Lactobacillus plantarum WCFS1 Fermentation Differentially Affects Antioxidant Capacity and Polyphenol Content in Mung bean (Vigna radiata) and Soya Bean (Glycine max) Milks," Journal of Food Processing and Preservation, vol. 41, no. 1, Article ID e12944, 2017.

[56] S. Li, C. Ma, G. Gong, Z. Liu, C. Chang, and Z. Xu, "The impact of onion juice on milk fermentation by Lactobacillus acidophilus," LWT- Food Science and Technology, vol. 65, pp. 543-548, 2016. 
[57] D. Hervert-Hernández, C. Pintado, R. Rotger, and I. Goñi, "Stimulatory role of grape pomace polyphenols on Lactobacillus acidophilus growth," International Journal of Food Microbiology, vol. 136, no. 1, pp. 119-122, 2009.

[58] C. Ankolekar, M. Pinto, D. Greene, and K. Shetty, "In vitro bioassay based screening of antihyperglycemia and antihypertensive activities of Lactobacillus acidophilus fermented pear juice," Innovative Food Science and Emerging Technologies, vol. 13, no. JANUARY, pp. 221-230, 2012.

[59] D. Das and A. Goyal, "Antioxidant activity and $\gamma$-aminobutyric acid (GABA) producing ability of probiotic Lactobacillus plantarum DM5 isolated from Marcha of Sikkim," LWT- Food Science and Technology, vol. 61, no. 1, pp. 263-268, 2015.

[60] W. Tang, Z. Xing, C. Li, J. Wang, and Y. Wang, "Molecular mechanisms and in vitro antioxidant effects of Lactobacillus plantarum MA2," Food Chemistry, vol. 221, pp. 1642-1649, 2017.

[61] N. Camu, T. De Winter, K. Verbrugghe et al., "Dynamics and biodiversity of populations of lactic acid bacteria and acetic acid bacteria involved in spontaneous heap fermentation of cocoa beans in Ghana," Applied and Environmental Microbiology, vol. 73, no. 6, pp. 1809-1824, 2007.

[62] J. C. Piard and M. Desmazeaud, "Inhibiting factors produced by lactic acid bacteria. 1. Oxygen metabolites and catabolism endproducts," Le Lait, vol. 71, no. 5, pp. 525-541, 1991.

[63] A. L. Freire, C. L. Ramos, and R. F. Schwan, "Effect of symbiotic interaction between a fructooligosaccharide and probiotic on the kinetic fermentation and chemical profile of maize blended rice beverages," Food Research International, vol. 100, pp. 698707, 2017.

[64] R. Tofalo, M. Schirone, G. Fasoli et al., "Influence of pig rennet on proteolysis, organic acids content and microbiota of Pecorino di Farindola, a traditional Italian ewe's raw milk cheese," Food Chemistry, vol. 175, pp. 121-127, 2015.

[65] S.-O. Yang, S.-H. Kim, S. Cho et al., "Classification of fermented soymilk during fermentation by $1 \mathrm{H}$ NMR coupled with principal component analysis and elucidation of freeradical scavenging activities," Bioscience, Biotechnology, and Biochemistry, vol. 73, no. 5, pp. 1184-1188, 2009.

[66] P.-R. Lee, Y.-L. Ong, B. Yu, P. Curran, and S.-Q. Liu, "Evolution of volatile compounds in papaya wine fermented with three Williopsis saturnus yeasts," International Journal of Food Science \& Technology, vol. 45, no. 10, pp. 2032-2041, 2010.

[67] H. Kelebek, S. Selli, H. Gubbuk, and E. Gunes, "Comparative evaluation of volatiles, phenolics, sugars, organic acids and antioxidant properties of Sel-42 and Tainung papaya varieties," Food Chemistry, vol. 173, pp. 912-919, 2015.

[68] W. Randazzo, O. Corona, R. Guarcello et al., "Development of new non-dairy beverages from Mediterranean fruit juices fermented with water kefir microorganisms," Food Microbiology, vol. 54, pp. 40-51, 2016.

[69] J. Gallegos, C. Arce, R. Jordano, L. Arce, and L. M. Medina, "Target identification of volatile metabolites to allow the differentiation of lactic acid bacteria by gas chromatography-ion mobility spectrometry," Food Chemistry, vol. 220, pp. 362-370, 2017.

[70] B. L. Gomes, J. P. Fabi, and E. Purgatto, "Cold storage affects the volatile profile and expression of a putative linalool synthase of papaya fruit," Food Research International, vol. 89, pp. 654-660, 2016.

[71] J. A. Pino, "Odour-active compounds in papaya fruit cv. Red Maradol," Food Chemistry, vol. 146, pp. 120-126, 2014.
[72] P.-R. Lee, I. S.-M. Chong, B. Yu, P. Curran, and S.-Q. Liu, "Effects of sequentially inoculated Williopsis saturnus and Saccharomyces cerevisiae on volatile profiles of papaya wine," Food Research International, vol. 45, no. 1, pp. 177-183, 2012.

[73] T. K. Singh, K. R. Cadwallader, and M. Drake, "Section XIV. Milk and Milk Products: Biochemical Processes in the Production of Flavor in Milk and Milk Products," Handbook of Food Products Manufacturing, vol. 2, pp. 715-748, 2006.

[74] M. Servili, C. G. Rizzello, A. Taticchi et al., "Functional milk beverage fortified with phenolic compounds extracted from olive vegetation water, and fermented with functional lactic acid bacteria," International Journal of Food Microbiology, vol. 147, no. 1, pp. 45-52, 2011.

[75] P. Melgarejo, Á. Calín-Sánchez, L. Vázquez-Araújo et al., "Volatile composition of pomegranates from 9 Spanish cultivars using headspace solid phase microextraction," Journal of Food Science, vol. 76, no. 1, pp. S114-S120, 2011.

[76] R. Di Cagno, R. F. Surico, A. Paradiso et al., "Effect of autochthonous lactic acid bacteria starters on health-promoting and sensory properties of tomato juices," International Journal of Food Microbiology, vol. 128, no. 3, pp. 473-483, 2009.

[77] R. Di Cagno, P. Filannino, and M. Gobbetti, "Lactic acid fermentation drives the optimal volatile flavor-aroma profile of pomegranate juice," International Journal of Food Microbiology, vol. 248, pp. 56-62, 2017. 


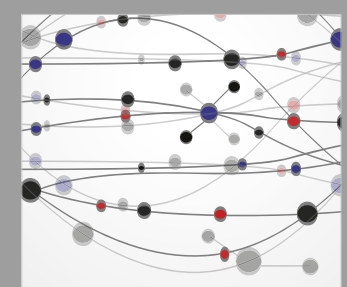

The Scientific World Journal
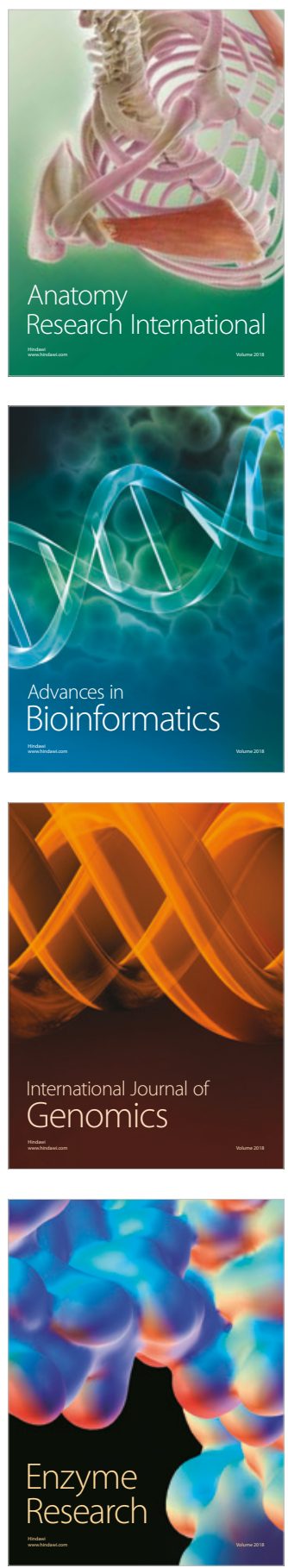
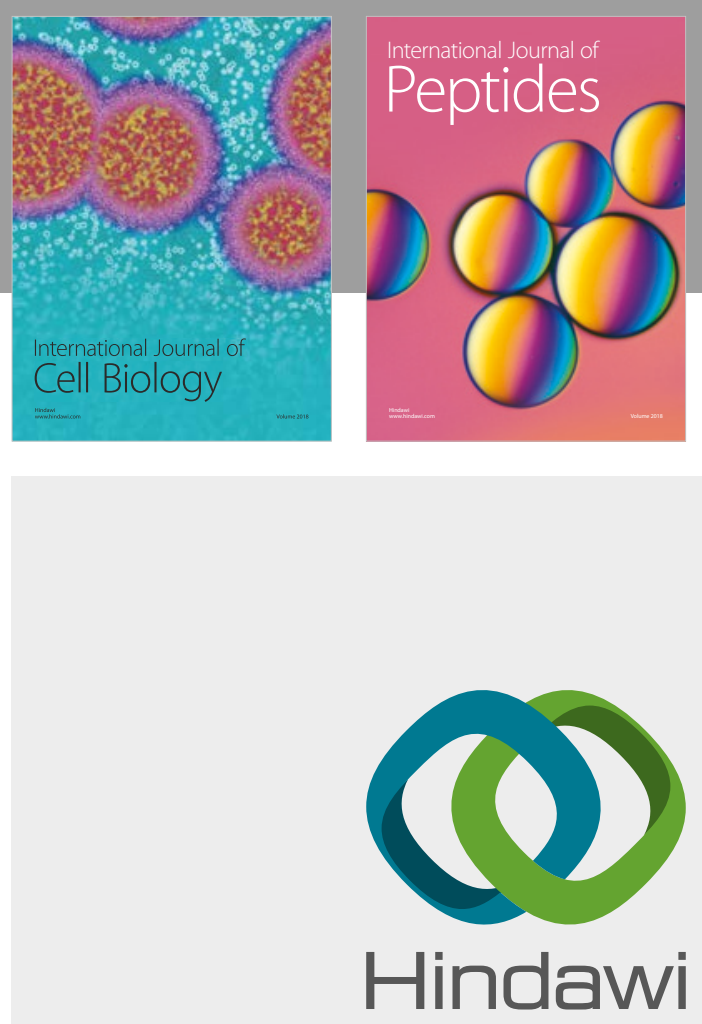

Submit your manuscripts at

www.hindawi.com
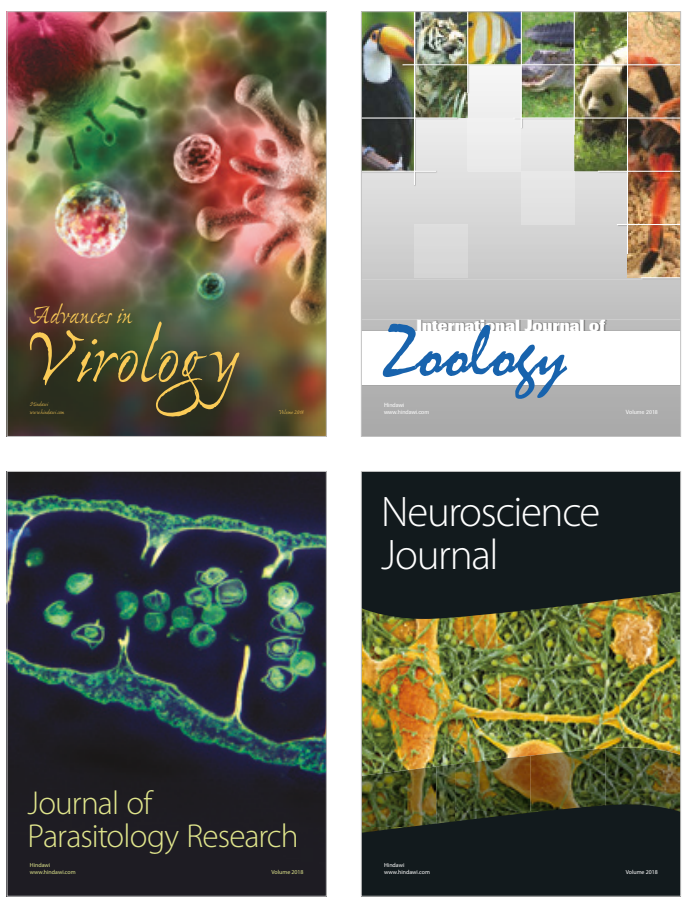
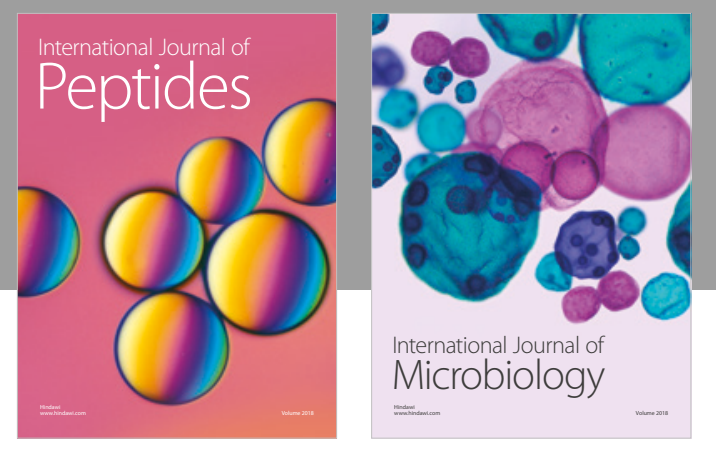

nternational Journal of Microbiology
Journal of
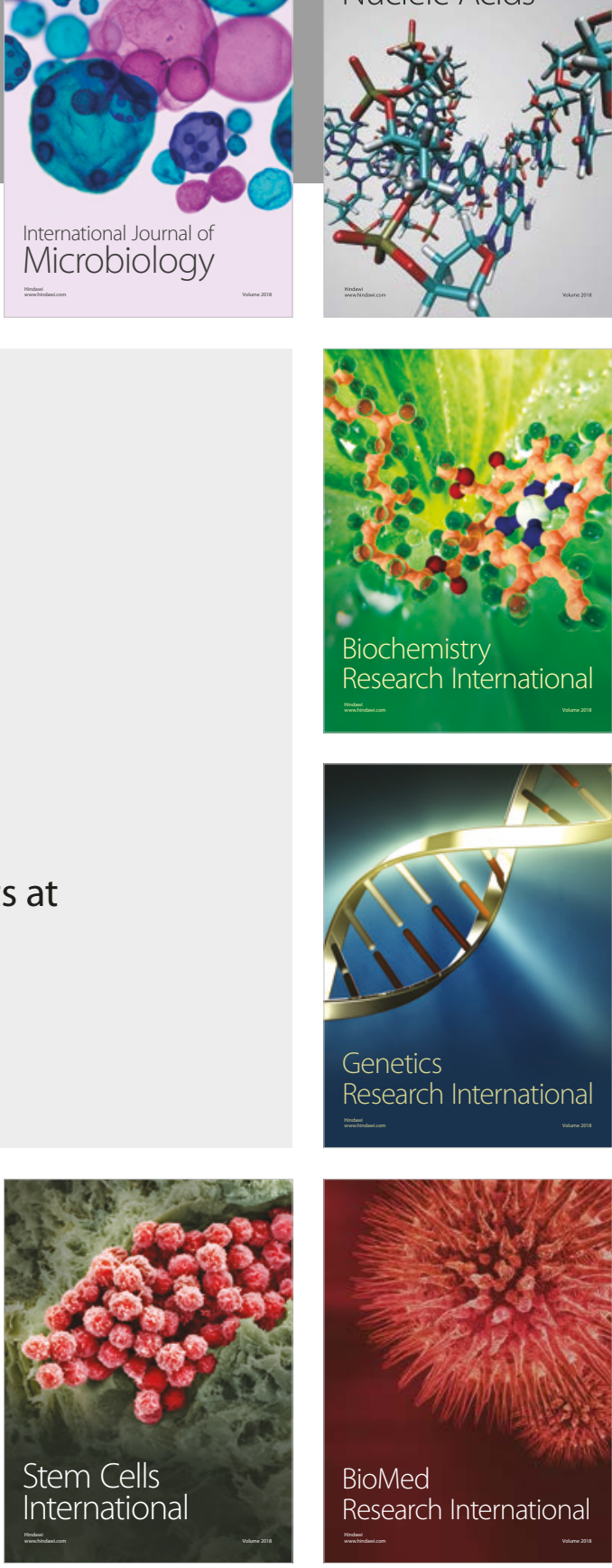
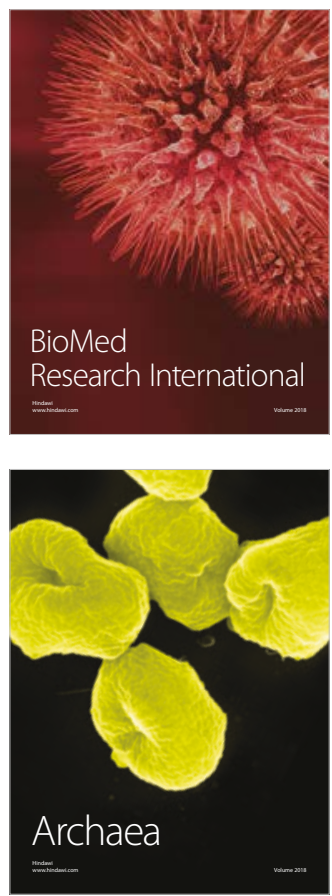